\title{
Sustainable Development Assessment on North Jakarta using Indicators and PLS-SEM
}

\author{
Lilyana $^{1 *}$, Naufal Sanca Lovandhika ${ }^{1}$, Rudy P. Tambunan ${ }^{2}$, Suyud Warno Utomo ${ }^{2}$, Teuku Yuri M \\ Zagloel $^{3}$, Lina Gozali ${ }^{4}$ \\ 1 Postgraduate Student, Environmental School, University of Indonesia, Jakarta, Indonesia \\ 2 Lecturer of Human Resource and Environment Study, University of Indonesia, Jakarta, Indonesia \\ 3 Lecturer of Industrial Engineering, University of Indonesia, Jakarta, Indonesia \\ 4 Lecturer of Industrial Engineering, Tarumanagara University, Jakarta, Indonesia
}

Received July $16^{\text {th }}, 2018$; accepted February $27^{\text {th }}, 2019$

Available online February 28 ${ }^{\text {th }}, 2019$

\begin{abstract}
Indonesia, as the second longest coastline country in the world, contain a huge coastal area need to be managed. One way to manage coastal area is using monitoring systems, yet none of them has been effectively implemented in Indonesia. This research attempts to develop monitoring system using indicators. There were 105 indicators that chosen from references. Each of the indicators were filtered by scoring method and then be processed using PLS-SEM resulting 9 indicators and sustainability development monitoring model. Coastal Area of North Jakarta has been chosen as area to implementing the model since that area are dynamics and growing rapidly. Based on the model, coastal area of North Jakarta has good economic condition (62.2\%), medium social condition (46.7\%), and bad natural environment condition (38\%). Sustainable development seems quite implemented in this area since the balance of Economic-Social-Natural Environment was on the medium and balanced category. By using GIS can be seen that the development that occurred in west side study area are better than middle or east side.
\end{abstract}

Keywords: Sustainable Development, Indicators, PLS-SEM, Coastal Area, Monitoring, GIS

\section{Introduction}

Indonesia is one of archipelagic country with about 17.504 island and $3.544 .743,9 \mathrm{~km}^{2}$ water area in the territory (Indonesia Ministry of Marine and Fisheries, 2011). Based on that fact, it is natural that Indonesia has the second longest coastline in the world with 202,080 km length of coastline (CIA, 2014). That means there is a huge coastal area need to be managed by Indonesian people. This should be one of prime concern of Indonesian government since coastal area is a strategic place for human being and known as fast-growing area, especially in urban area. According to the United Nations Environment Program (UNEP), half of the world's population live at a distance of $60 \mathrm{~km}$ from the coast area. About $75 \%$ of Big Cities in the world are located on the coast (UNEP, 2015). In the country's scale, as the country of America is around $39 \%$ of the population live in the administrative regions that having a coastal area. Similarity happens in Indonesia, according to the Kehati (2013) population that living in coastal area in Indonesia has reached 161 million of people or $60 \%$ of the 250 million population of Indonesia. If there is no special treatment, it can be a problem for Indonesia. The development will uncontrolled and can cause environmental capacity problem as mentioned in some report about environmental capacity problem in Indonesia. Therefor good management concept of coastal area is needed.

\footnotetext{
* Corresponding author

E-mail address: lilyjapjaplily@ gmail.com
} 
One of Indonesian coastal area that growing rapidly is North Jakarta. In 1950, the land has been used for settlements in Jakarta were only $11.5 \%$ of the total area. In 2008, the settlements are has been increased up to $86.2 \%$ of the total area (Kunu \& Lelolterry, 2010). Until now, Jakarta continues to grow rapidly. The rapid growth of Jakarta comes from changes in land use. Changes in land use amounted to $74.7 \%$ within 58 years. This is in line with the increasing number of inhabitants of Jakarta, according to BPS recorded in 1971 a population of 4,579,303 inhabitants, whereas in 2010 amounted to 9,607,787 people (BPS, 2010). Increasing population has also reached more than 5 million lives in the last 40 years. The amount of increase in the population of Jakarta in the period 1971-2010 is a large number when compared with other provinces in Indonesia (with a record area of the province accounted for in comparison). Population growth is also accompanied by an increase in the office, industrial, infrastructure and other sectors required by the population. Coastal area of North Jakarta that has evolved from the 5th century (Jakarta History, 2008), according to Arifin (2004), now receive the cumulative impact load Jakarta Kota (Land-Based Pollution). Jakarta Bay is administratively located in North Jakarta, receiving a high enough volume of pollutants from the mainland were higher by 13 rivers that flow into the bay. The 13 rivers include Angke, Bekasi, Cakung, Cidurian, Ciliwung, Cikarang, Cimancuri, Ciranjang, Cisadane, Citaru, Karawang, Krukut, and Sunter River. This is the reason why it is necessary to study the suitability of the condition of the coastal area of North Jakarta with Sustainable Development Indicators as part of the framework of Sustainable Development.

Sustainable development concept has begun being implemented Since 1987 with the publication of WCED. Many big cities in the world supporting the program. In Indonesia, sustainable development has been implemented since 2005 in the long-term development plan, but there is no clue how it implemented and what is the status, it is bad or good implemented. Thus, researchers are trying to examine what happened based on facts with a study entitled Coastal Area Sustainable Development Assessment on North Jakarta using Indicators and PLS-SEM. This research is considered very important to support policies that began to lead to the concept of sustainability. This is also in accordance with the opinion of The Encyclopedia of Earth that says "You will not be able to recognize, understand, improve, or maintain what you cannot measure". Given this research, each region will have a benchmark in the balance of economic, social, and natural environment. In addition to this judgment, this study will get the latest conditions of the study area to which the concept of sustainability has been applied to areas throughout Indonesia so that decisions can be made regarding this matter.

\section{Materials and Methods}

The study was conducted in the Coastal area in North Jakarta which consists of 5 sub district like Penjaringan, Pluit, Pademangan, Tanjung Priok and Cilincing. The reasons for selecting the coastal area in North Jakarta due to one of the coastal urban areas who have experienced the most rapid development in Indonesia. A total of 105 indicators have been obtained from sustainable development indicators references, SUSTAIN (2012), DEDUCE (2007), and Arcadis (2015), to assess the economic, social, and natural environment in research area. The indicators are given a score based on the accessibility of data, spatial coverage of data, temporal coverage of data, and data reliability. Indicators with a sufficient score then used to construct models of PLS-SEM with Balance as Latent Variable. The calculation of the value of the variable social, economic, and environmental based on the calculation of regression equations derived from the model. Results of these values were analyzed descriptively. Values of these variables then also be spatially illustrated with GIS in the form of maps to be analyzed spatially.

\section{Result}

Appropriate Indicators to Assess Aspects of Economic, Social, and Natural Environment of Coastal Area 
The output of scoring assessment show 20 indicators that meet the requirements the indicator with a score over 16. The next step method result (developing PLS-SEM Model) give out 9 from 20 Indicators as appropriate Indicators to Assess Aspects of Economic, Social, and Natural Environment. In addition to determining the appropriate indicators for the third aspect, the method also produces PLS-SEM weights (regression coefficient) of each of the indicators in the form of each aspect or better known as the Weight Indicator. The weights of the indicators used in calculating the value of each variable. The weights indicate the magnitude of the indicator compared to other indicators in forming latent variables. The regression equation of each of these aspects are:

$\mathrm{NE}=0,398 \mathrm{~L} 5+0,430 \mathrm{~L} 6+0,505 \mathrm{E} 1$

NE : Natural Environment Aspect Value

L5 : Waste Management Indicator Value

L6 : Vegetation Cover Indicator Value

E1 : Population Density Indicator Value

$\mathrm{S}=0,456 \mathrm{~S} 1+0,440 \mathrm{~S} 2+0,404 \mathrm{~S} 4$

S : Social Aspect Value

S1 : Poverty Indicator Value

S2 : Attendance to festivals and public events, organized to strengthen the area's local identity Indicator Value

S4 : Crime Indicator Value

$\mathrm{E}=0,420 \mathrm{E} 6+0,440 \mathrm{E} 8+0,404 \mathrm{~S} 3$

E : Economy Aspect Value

E4 : Distance from Harbor/Jetty Indicator Value

E6 : Property Price Indicator Value

S3 : Provision of Health Care Services Indicator Value

$\mathrm{B}=0,085 \mathrm{NE}+0.587 \mathrm{~S}+0.540 \mathrm{E}$

B : Composite Value

NE : Natural Environment Aspect Value

$\mathrm{S} \quad$ : Social Aspect Value

E : Economy Aspect Value

Given the regression equation, the value of each variable can be calculated. After the value of these three variables are known then the value of any variable balance so that it can also be known as the balance of the value of the variable composite index of the three aspects and their balance status. 
Table 1. Chosen Indicators using Scoring and PLS-SEM Modeling

\begin{tabular}{|c|c|c|c|}
\hline No. & Aspect & Indicator & Value $(\%)$ \\
\hline 1 & \multirow{3}{*}{$\begin{array}{l}\text { Natural } \\
\text { Environment }\end{array}$} & Waste Management & 31,1 \\
\hline 2 & & Vegetation Cover & 18,7 \\
\hline 3 & & Population Density & 59,8 \\
\hline \multicolumn{3}{|c|}{ Natural Environment Value } & 38,0 \\
\hline 4 & Social & Poverty & 61,5 \\
\hline 5 & & $\begin{array}{l}\text { Attendance to festivals } \\
\text { and public events, } \\
\text { organized to } \\
\text { strengthen the area's } \\
\text { local identity }\end{array}$ & 40,5 \\
\hline 6 & & Crime & 48,3 \\
\hline \multicolumn{3}{|c|}{ Social Value } & 46,7 \\
\hline 7 & Economy & $\begin{array}{l}\text { Distance from Harbor } \\
\text { /Jetty }\end{array}$ & 79,2 \\
\hline 8 & & Property Price & 50,1 \\
\hline 9 & & $\begin{array}{l}\text { Provision of Health } \\
\text { Care Services }\end{array}$ & 56,7 \\
\hline \multicolumn{3}{|c|}{ Economy Value } & 62,2 \\
\hline
\end{tabular}

Coastal Area of North Jakarta Economy, Social, and Natural Environment status

North Jakarta coastal economy status is in good category. It can be seen from the value of the three indicators of distance from the harbor/Port, Property Prices, and Availability of Health Services (See Table 2). Of the five districts, four of which include both categories namely District Koja, Pademangan, Penjaringan and Tanjung Priok. A total of 1 districts included in the category of bad economic conditions that is Cilincing. In a more detailed scale value per village economic conditions vary from very poor category to Very Good. There are 3 Sub categorized as very poor, 2 poor village by category, 4 Village with enough categories, 15 village with good category, and four village with very good category.

North Jakarta coastal social conditions in the category enough. It can be seen from the value of the three indicators namely Poverty Level, Level of Participation in Local Events, criminality (see Table 4.8). A total of 5 districts, has been divided based on assessment categories. A district of which include both the District Pademangan category. A total of three districts in the category of social conditions is quite namely District Koja, Penjaringan and Tanjung Priok sub district as well, one districts rest goes into the category of bad, i.e. Cilincing sub district. In a more detailed scale value per village social conditions vary from poor to excellent category. There are 8 village with bad category, 15 Village with enough categories, and 5 village with good category. 
Table 2. Indicators and Aspects Value based on Model Equation

\begin{tabular}{|c|c|c|c|}
\hline No. & Aspect & Indicator & Value $(\%)$ \\
\hline 1 & \multirow{3}{*}{$\begin{array}{l}\text { Natural } \\
\text { Environment }\end{array}$} & Waste Management & 31,1 \\
\hline 2 & & Vegetation Cover & 18,7 \\
\hline 3 & & Population Density & 59,8 \\
\hline \multicolumn{3}{|c|}{ Natural Environment Value } & 38,0 \\
\hline 4 & Social & Poverty & 61,5 \\
\hline 5 & & $\begin{array}{l}\text { Attendance to festivals } \\
\text { and public events, } \\
\text { organized to } \\
\text { strengthen the area's } \\
\text { local identity }\end{array}$ & 40,5 \\
\hline 6 & & Crime & 48,3 \\
\hline \multicolumn{3}{|c|}{ Social Value } & 46,7 \\
\hline 7 & Economy & $\begin{array}{l}\text { Distance from Harbor } \\
\text { /Jetty }\end{array}$ & 79,2 \\
\hline 8 & & Property Price & 50,1 \\
\hline 9 & & $\begin{array}{l}\text { Provision of Health } \\
\text { Care Services }\end{array}$ & 56,7 \\
\hline \multicolumn{3}{|c|}{ Economy Value } & 62,2 \\
\hline
\end{tabular}

North Jakarta coastal Natural Environment conditions included in bad category. It can be seen from the value of the three indicators, namely availability Waste Management, Vegetation cover, and Population Density. A total of five districts, has been divided based on assessment categories. A district of which include the category of very bad that Koja sub district. A total of two districts in the category of poor environmental conditions that Pademangan sub-district and district of Tanjung Priok, as well as the two remaining districts in the category enough, ie Cilincing sub district and Penjaringan. In a more detailed scale value per village varying environmental conditions of the category of very poor to very good. There are 7 Sub categorized as very poor, poor village by category, 8 village with enough categories, and six village with good category.

\section{Economy-Social-Natural Environment Balance in North Jakarta Coastal Area}

The economic, social, and environment balance of in the coastal area of North Jakarta in the category fairly and balanced. It can be seen from the values and social status with a value of 38.16 categorized as poor, the economic worth 53.62 categorized enough, and the natural environment with the value of 37.93 has been categorized as bad. The calculation of composite values taken from the balance of the value of these three aspects and the resulting equilibrium value of 52.79 as the basis of determining the category of the coastal area of North Jakarta. Calculations and the same explanation and deeper also allocated for each district to village.

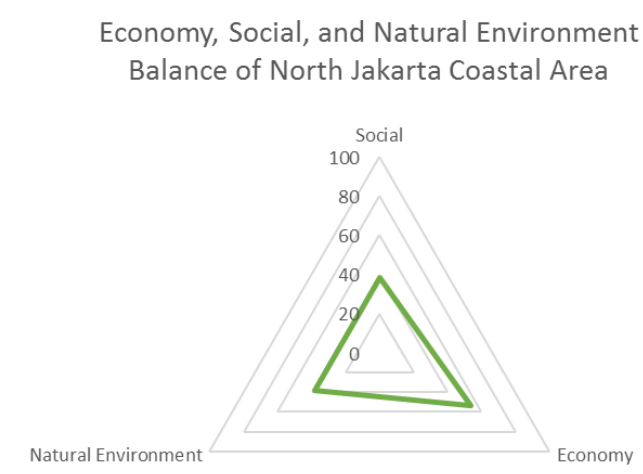

Figure 1. Economy, Social, and Natural Environment Balance of North Jakarta Coastal Area Radar Chart 
It found two new patterns in the results of the analysis. The first pattern is found that in the category of pretty but unbalanced where the imbalance caused by the economic variable value is always higher than the value of other variables. Village with enough categories but not balanced the Lagoa Urban Village, South Rawabadak, North Rawabadak, Slaughter, Warakas, Kebon Bawang, Papango, Sungai Bambu has a value higher economic variables compared with the value of other variables. This shows that when there is an imbalance in the balance of the area with a composite score enough cause is the economic aspect takes precedence over social and natural environmental aspects, not because of natural environmental aspects and social aspects too prominent.

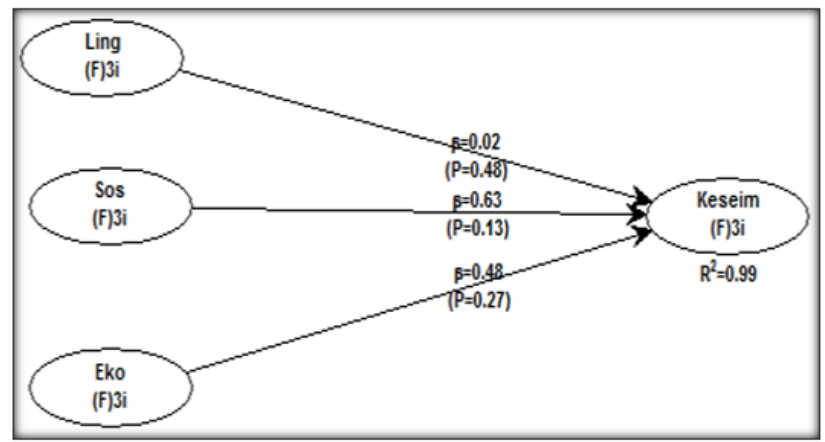

Figure 2. Economy, Social, and Natural Environment Balance of North Jakarta Coastal Area in SEM-PLS Formulation and ratio

The second pattern is found that in villages with bad category and are not balanced, the natural environmental aspect is always higher than the social and economic aspects. Village with bad category and not balanced the village Cilincing, Marunda, and Rorotan has a value higher than the natural environmental variables other variables. This shows two things:

1. Village of the categories bad and unbalanced relatively unexploited so that their natural environmental aspects are still in good condition with undeveloped economic conditions.

2. There are clear conflicts between economic and natural environmental aspects. If the increased economic aspects and the composite value of balance begins to rise from the bad category will be enough signage potential economic aspects will be more prominent than other aspects and cause an imbalance. Teresbut potential magnitude is $50 \%$ the proportion of villages with enough categories and balanced with sufficient administrative category but unbalanced 8: 8 or $50: 50$.

Based on the analysis, spatial equilibrium level coastal areas of North Jakarta has a pattern that tends to decline from the west to the east (where the coastal North Jakarta City is divided into 3 sections spatially). It can be seen in Figure 3.2. The western part of North Jakarta coastal town dominated by the village with a good and balanced category ( 3 villages out of a total of 5 villages). The middle part is more varied than the west and tend no dominant category. The middle section is filled with 2 villages either category and balanced, two villages either category but are not balanced, two villages dengna enough categories and balanced, as well as three village with enough categories but not balanced. The eastern part is dominated by two categories of the outer edge of relatively equal size. The category of the categories bad and unbalanced ( 3 villages) and enough categories and unbalanced ( 7 villages). This pattern suggests that the North Jakarta coastal development is uneven. Construction more severe in the western part. Further studies to determine whether the development of the west to the east or indeed just centralized in the western part. 


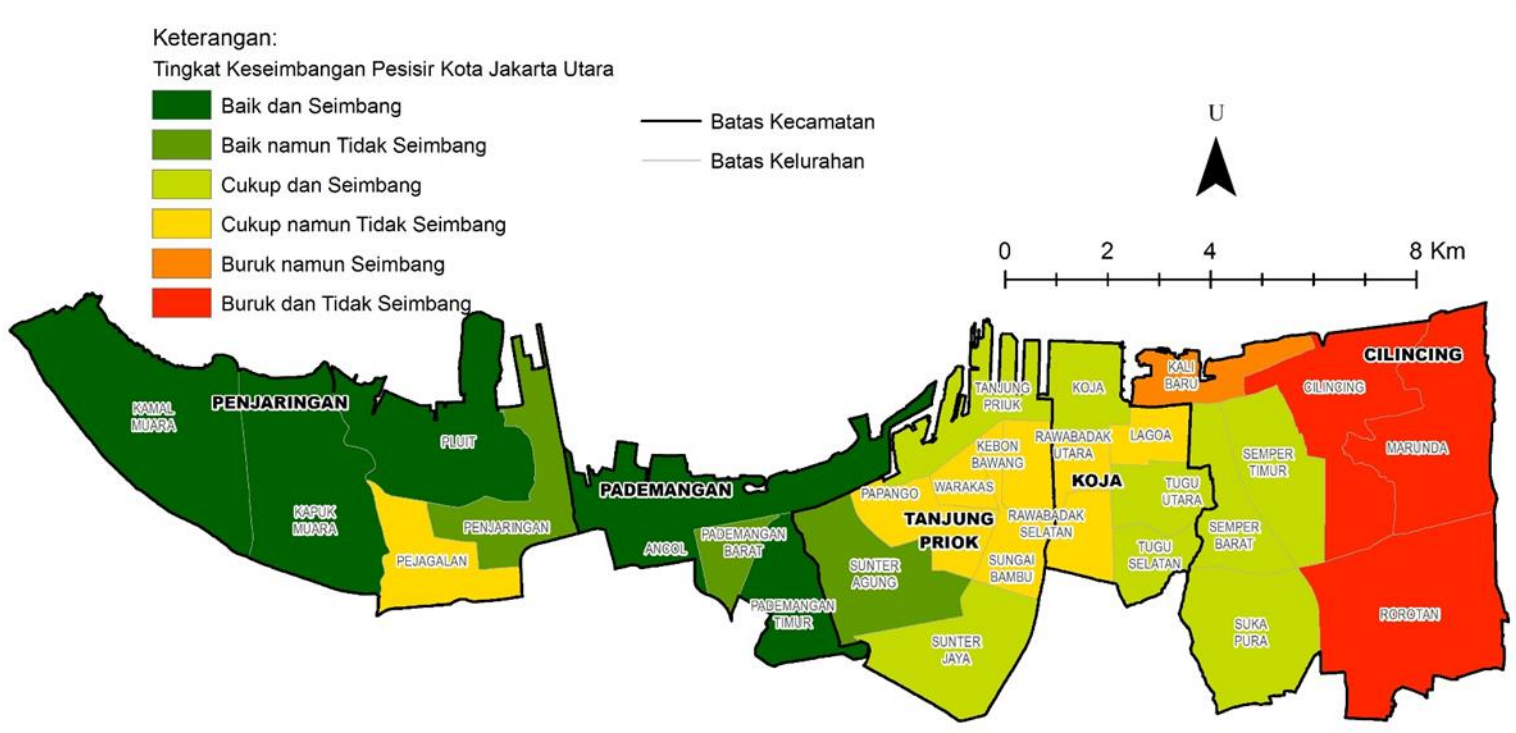

Figure 3. Economy, social, and Natural Environment Balance of North Jakarta Coastal Area Map

If the note in Figure 3, the distribution pattern of balance categories tend to cluster or terklaster. There are 3 groups / clusters, ie clusters combined value good balance (located at the west), pretty (located at the western, central and eastern) and bad (located in the eastern part). This suggests that the improvement in conditions of economic, social and natural environment can not be separated, for example, the increase is done in one keluruahan in the east and one village in the western part. Should increase carried out simultaneously in the eastern part first.

\section{Discussion}

Found concordance between the results of analysis with actual field conditions. For example Ancol urban village in the category of good balance and balanced because the value of the Economics, Social and Natural environment quite enough. Value Village Economic Aspects Ancol supported by the tourism sector contained in this district namely Taman Impian Jaya Ancol and Fantasy World (Dufan) (See Figure 3). The number of visitors of the tourist destinations that make the value of the economic aspects of Ancol Urban Village in the category enough. In addition there is also an elite housing in the village. Natural environmentally and Socially Ancol Urban Village has a balanced value because it has a large enough area of vegetation as well as social facilities

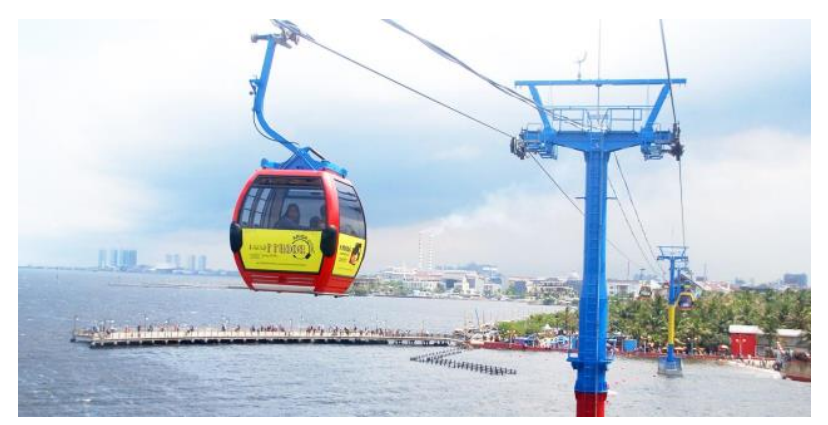

Figure 4. Tourism Object in Ancol Sub district (Taman Impian Jaya Ancol) ${ }^{1}$

Kamal Muara Village of Good and Balanced category. This is because the village has a value Kapuk Muara good economic aspects, as well as the natural environment, the social aspects of the category

\footnotetext{
${ }^{1}$ https://www.ancol.com/id/destinasi/gondola
} 
enough. The economic aspects of Kapuk Muara Village quite well one of them caused by the presence of elite housing, hospitals and other luxury amenities.

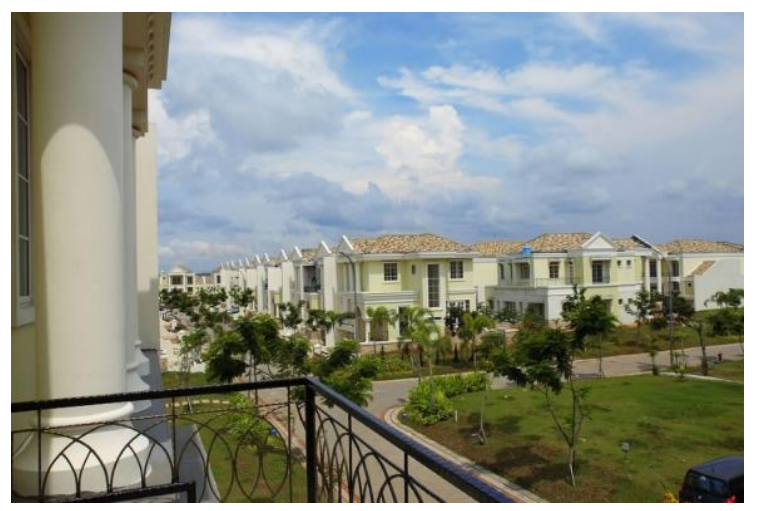

Figure 5. High Price Property in Kapuk Muara sub district

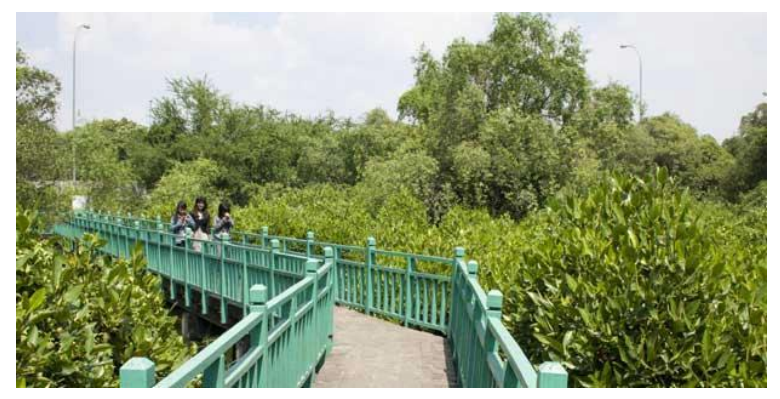

Figure 6. Mangrove Forest in Kamal Muara sub district

For the natural environmental aspect Kapuk Muara Village has a high value area of vegetation and protected beach because there Muara Angke Wildlife (SMMA) that have mangrove forests in it. In the social aspect of Kapuk Muara village has supporting facilities were very well social activities such as tourist sites, educational centers (schools), entertainment, religion (Buddhism Tsuchi Centre) so that the value of the social aspects of the Village Kapuk Muara including high category.

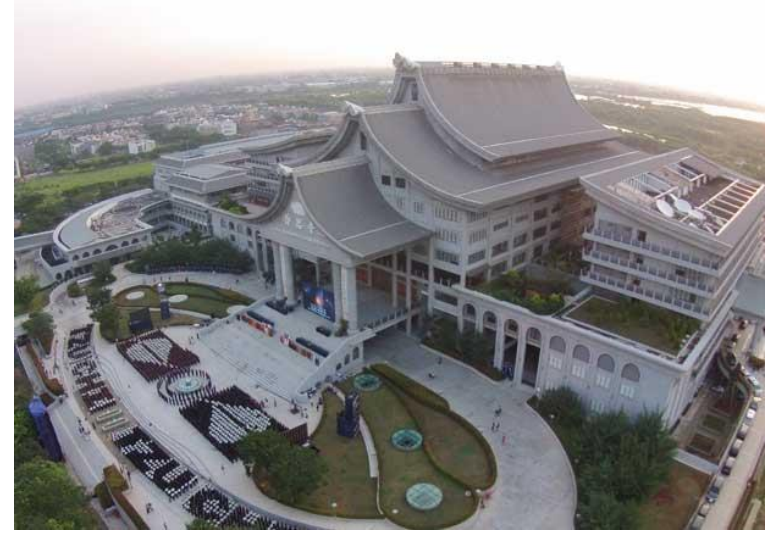

Figure 7. Buddha Tzu Chi building in Kamal Muara sub district ${ }^{2}$

Reality on the ground to the lowest category also suitable. For example, Cilincing Sub categorized as poor balance and imbalance. This condition is, in accordance with conditions on the ground that the

\footnotetext{
${ }^{2}$ http://www.tzuchi.or.id/read-berita/waisak-2558-kisah-dari-balik-layar/4355
} 
area is known to the slums with poor natural environmental (see Figure 7). This is consistent with that reported by Cilincing Sub Post City that has 2 RW with status Jakarta slum se (http://poskotanews.com/2015/10/26/jakarta-utara-masih-punya-2-rw-super-kumuh) In terms of the economic and social areas are poor and often social conflicts, especially crime.

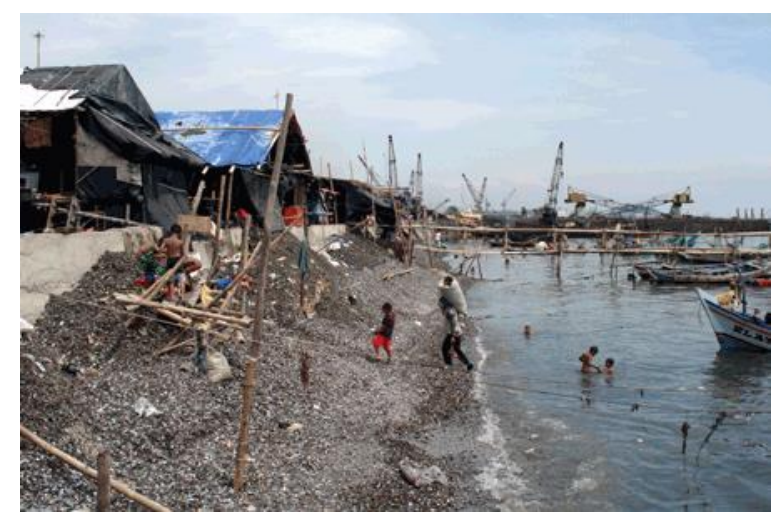

Figure 8. Cilincing sub district coastal area

\section{Conclusion}

1. Indicators appropriate for assessing the economic aspects of coastal North Jakarta is the property price, distance from the Port and Availability of Health Facilities. Appropriate indicators to assess the social aspects of coastal North Jakarta is the Poverty Level, Level of Public Participation in Local Activities and Level Crime. Appropriate indicators to assess the natural environmental aspect is Waste Management, Vegetation Cover, and Population Density

2. In general, the economic conditions of North Jakarta included in either category with a value of $62.2 \%$. North Jakarta Social conditions included in the category enough with a value of $46.7 \%$. Natural environmental conditions of North Jakarta included in the category of bad with a value of $38.0 \%$

3. The economic aspects, social and natural environmental coastal North Jakarta City included in the category enough and balanced, mean indicates that the condition of the coastal areas of sustainable (Sustainability)

\section{Reference}

Arcadis. (2015). Sustainable Cities Index 2015 Balancing the economic, social and environmental needs of the world's leading cities. http://www.sustainable citiesindex.com, 12 January 2015, pk. 19.00 WIB.

Arifin, Z. (2004). Local Millenium Ecosystem Assessment: Condition and Trend of the Greater Jakarta Bay Ecosystem. Jakarta: Ministry of Environment Republic Indonesia.

Bernhardsen, T. (1992). Geographic Information Systems: An Introduction. Viak: IT/Norwegian Mapping Authority

BPS. 2010. Statistik Indonesia. Jakarta: Badan Pusat Statistik.

Central Intelligence Agency. (2014). The World Factbook (2014-2015 edition). United States: Directorate of Intelligence

DEDUCE. (2007). Consortium, Indicators Guidelines: to Adopt an Indicators-based Approach to Evaluate Coastal Sustainable Development. Catalonia: Department of the Environment and Housing, Government of Catalonia.

Foote, K. E. dan Lynch, M. (1996). Geographic Information Systems as an Integrating Technology: Context, Concepts, and Definitions. USA: University of Texas.

Jakarta History. (2008). http://www.jakarta.go.id/v2/news/1970/01/Sejarah-Jakarta\#.VhWq7Pmqqko, 6 May 2015 pk. 20.00 WIB. 
Kunu, P. J. dan Lelolterry, H. (2010). Penggunaan Lahan dan Evolusi Penggunaan Lahan di Provinsi DKI Jakarta. Jurnal Agroforestri Vol. V No. 3

Kehati. (2013). Ekosistem Pesisir dan Pulau-pulau Kecil. http://kehati.or.id/id/site _content/11program/36-ekosistem-pesisir-dan-pulau-pulau-kecil.html, 6 Mei 2015, pk. 20.00 WIB.

Kuswartoyo, T. (2006). Asas Kota Berkelanjutan dan Penerapannya di Indonesia. Jurnal Teknik Lingkungan P3TL-BPPT.7.(1), 1-6.

Indonesia Ministry of Marine and Fisheries. (2011). Kelautan dan Perikanan dalam Angka 2011. Jakarta: Pusdatin-KKP

Salim, Emil., Ratusan Bangsa Merusak Satu Bumi, Jakarta: Penerbit Buku Kompas, 2010.

Schernewski, G., Schonwald, S., Katarzyte, M. (2014). Application and Evaluation of an Indicator Set to Measure and Promote Sustainable Development in Coastal Areas. Ocean and Coastal Management, 101, 2-13.

Singh R. K., Murty, H. R., Gupta, S. K., Dikshit, A.K. (2012). An Overview of Sustainability Assessment Methodologies. Ecological Indicators, 15, 281-299..

SUSTAIN partnership. (2012). The SUSTAIN Indicator set. A set of easily measurable sustainability indicators. 19 pp. http://www.sustain-eu.net/what_are_we_doing/sustain_indicator_set.pdf, 8 Oktober 2015, pk. 20.00 WIB

UNEP. (2015). Cities and Coastal Areas. http://www.unep.org/urban_environm ent/issues/coastal_zones.asp, 6 Mei 2015, pk. 20.00 WIB.

WCED (World Commision on Environment and Development). (1987). Our Common Future. Oxford: Oxford University Press.

ud.com/newworldpunx/asot650utrecht 